\title{
Effects of feruloyl esterase-producing lactic acid bacteria or cellulase on anaerobic fermentation profiles, lignocellulosic degradation, enzymatic hydrolysis and methane production potential of co- ensiled corn stalk and potato pulp
}

Dongmei $\mathrm{Xu}$

Lanzhou University

Zitong Ding

Lanzhou University

Wencan Ke

Lanzhou University

Jie Bai

Lanzhou University

Yixin Zhang

Lanzhou University

Fuhou Li

Lanzhou University

Xusheng Guo ( $\sim$ guoxsh07@lzu.edu.cn )

Lanzhou University https://orcid.org/0000-0002-5587-3920

Research

Keywords: Co-ensiling, Theoretical methane yield, Silage additives, Solanum tuberosum, Zea mays

Posted Date: December 9th, 2019

DOI: https://doi.org/10.21203/rs.2.18472/v1

License: (c) (i) This work is licensed under a Creative Commons Attribution 4.0 International License.

Read Full License 
Effects of feruloyl esterase-producing lactic acid bacteria or cellulase on anaerobic fermentation profiles, lignocellulosic degradation, enzymatic hydrolysis and methane production potential of co-ensiled corn stalk and potato pulp

Dongmei $\mathrm{Xu}^{1,2}$, Zitong Ding ${ }^{1,2}$, Wencan $\mathrm{Ke}^{1,2}$, Jie Bai ${ }^{1,2}$, Yixin Zhang ${ }^{1,2}$, Fuhou $\mathrm{Li}^{1,2}$, Xusheng Guo ${ }^{1,2 *}$

${ }^{1}$ State Key Laboratory of Grassland and Agro-ecosystems, School of Life Sciences, Lanzhou University, Lanzhou 730000, PR China.

${ }^{2}$ Probiotics and Biological Feed Research Center, Lanzhou University, Lanzhou 730000, PR China

*Corresponding author: Dr. Xusheng Guo, School of Life Science, Lanzhou University, No. 222 South Tianshui Road, Lanzhou 730000, PR China.

Tel: +86 13919355253;

Fax: +86 09318915650 ;

E-mail address: guoxsh07@ 1zu.edu.cn (X.S. Guo) 


\section{Abstract}

Background: Anaerobic digestion of agro-industrial residues that with rich lignocellulosics biomass is regarded as one of the cost-efficient and environmentally beneficial technologies for biofuels production. While, pretreatment is necessary to degrade cellulose and hemicellulose for enhancing the potential bio-digestibility process for biogas producing. Thus, the effects of co-ensiling of corn straw and potato pulp inoculated with ferulic acid esterase-producing Lactobacillus plantarum A1 or cellulases on lignocellulosic degradation, enzymatic hydrolysis and theoretical biochemical methane potential were investigated with two mixture ratios. Four treatments were applied: without additive (C), L. plantarum A1 (P), cellulases (E) and combination of L. plantarum A1 and cellulases $(\mathrm{P}+\mathrm{E})$. Two mixture ratios were used: weight ratio of wet corn straw (rehydrated to $460 \mathrm{~g} / \mathrm{kg}$ fresh weight) and potato pulp of 4:1 (CP) and weight ratio of dry corn straw and potato pulp of 1:2 (PC).

Results: The results revealed that silages treated with $\mathrm{E}$ and $\mathrm{P}+\mathrm{E}$ performed better regarding lignocelluloses degradation by lowering the contents of lignocelluloses with prolonged fermentation time and preserved more available carbohydrates. The $\mathrm{P}$ and $\mathrm{C}$ resulted in greater enzymatic hydrolysis as indicated by higher glucose yield, cellulose convertibility and relative improvement ratio especially at 60 and $90 \mathrm{~d}$ of co-ensiling. For biofuels producing, the CP ratio of mixture had higher theoretical methane yield than $\mathrm{PC}$ ratio. Therefore, Co-ensiling $\mathrm{CP}$ ratio with additives $\mathrm{E}$ and $\mathrm{P}+\mathrm{E}$ for $90 \mathrm{~d}$ might be considerable pretreatment of mixed corn stalk and potato pulp 
for biogas production.

Conclusions: This work will helpful in investigating pretreatment of biomass that with rich lignocellulosics. In addition, the visualization results of the process of lignocellulosic degradation could be used for guidance to explore the lignocellulosic biomass using for large-scale biofuels production.

Keywords: Co-ensiling, Theoretical methane yield, Silage additives, Solanum tuberosum, Zea mays

\section{Background}

Concern over global climate change, high worldwide requirement for energy and energy crisis have led to attention on renewable energy that can displace fossil transportation fuel $[1,2]$. Energy from biomass and waste, as well as agro-industrial residues, is regarded as one of the most dominant renewable energy sources, since it can provide a continuous power and is environmentally friendly form. The agro-industrial residues led to environmental issues, and often constitute a substantial source of pollution [3, 4]. Meanwhile, increased attention has been focused on biogas production from agroindustrial residues that with rich lignocellulosics biomass. Anaerobic digestion of agroindustrial residues has been considered as one of the most cost-efficient and environmentally beneficial technologies [5], which has been paid close attention in recent years. Methane derived by anaerobic digestion has proved to be competitive with heat, steam and ethanol production in efficiency, environmental impact and cost of the 
conversion of waste streams to energy forms [1].

Corn stalk is one of the most abundant agricultural residues, while most of corn stalk is primarily disposed by burning, water-logged compost and discarding [6]. However, high content of fiber including cellulose, hemicellulose, lignin and their association hampers biological conversion during anaerobic digestion [7, 8]. Hydrolysis reaction is limited by a recalcitrant lignocellulose complex that resists assault of the microbial and enzymatic process [2]. Therefore, it is necessary to pre-treat these lignocellulosics substances prior to anaerobic digestion to enhance their potential bio-digestibility process for biogas producing. Modified ensiling process with cellulolytic and hemicellulolytic enzymes could degraded amounts of cellulose and hemicellulose [9]. Hence, corn stalk has great potential after pre-treatment with cellulase for biogas production, which would benefit society by providing a clean fuel. Potato pulp, a mixture of potato peels, starch and fats obtained after the productions of starch, which is one of the agro-industrial residues that are available in China. It can be used as animal feed, but often gets mouldy and becomes useless as animal feed and unfriendly to environment in a short time [10]. Furthermore, the cost of drying is high and then it is not financially rewarding. Ensiling can be recognised as an efficient way of preserving high moisture content by-products [11]. However, low water-soluble carbohydrate, low amount of lactic acid bacteria population and high moisture limit the aptitude of potato pulp be ensiled $[12,13]$. According to Zhang et al., [14], ensiling mixed potato pulp with other agricultural byproducts have produced satisfactory feed quality. Thus, we hypothesis that mixture of 
corn stalk and potato pulp after co-ensiling would efficiently provide a kind of good substrate for biogas production.

Furthermore, ferulic acid is one of the phenolic constituents present in cell walls of several plants, which is one of the inhibitory factors to the digestibility of plant cell wall polysaccharides $[15,16]$. However, it has been reported that the release of ferulic acid from cell walls is good for enzymatic degradation of cell wall polysaccharides [17]. In addition, ferulic acid esterase (FAE) with activity to break the ether bonds between lignin and polysaccharides of forages [18] can be produced from lactic acid bacteria (LAB) [19]. Previous study indicated that ferulic acid esterase-producing inoculants had negative effect on fiber degradability and use of fiberolytic enzymes does not have a major effect on the fiber degradability or when applied in combination with inoculant in alfalfa silage [20]. Different LAB strain performed various effects on fiber digestibility in ensiled forage [19]. Furthermore, FAE-producing Lactobacillus buchneri mixture inoculants improved fiber digestibility [21]. To our best knowledge, few studies have been focused on pre-treat agro-industrial residues with FAE-producing LAB in combination with cellulase for biogas production potential. The objective of this study was to investigate the pre-treatment efficiency of fermentation, lignocellulosic degradation, enzymatic hydrolysis and biogas production potential from co-ensiled corn stalk and potato pulp inoculated with FAE-producing LAB or cellulase.

\section{Results and Discussion}

\section{Characteristics of mixtures of corn stalk and potato pulp before and after co-}




\section{ensiling}

The characteristics of mixtures of corn stalk and potato pulp before and after co-ensiling with additives are listed in Table 1 and Table 2. The PC ratio of mixture had lower $\mathrm{pH}$ than $\mathrm{CP}$ ratio, and the $\mathrm{E}$ and $\mathrm{P}+\mathrm{E}$ treatments induced lower $\mathrm{pH}$ than $\mathrm{C}$ and $\mathrm{P}$ treatments in mixture with $\mathrm{PC}$ ratio $(P<0.001)$. The $\mathrm{pH}$ in the present study was lower than ensiling corn stalk alone with L. plantarum A1 or cellulase or their combination [22]. It suggested that the potato pulp could enhance the decrease of $\mathrm{pH}$ and become more effective with greater proportion. Compared with control group, additives decreased the concentration of lactic acid in $\mathrm{CP}$ ratio, but increased in $\mathrm{PC}$ ratio added with $\mathrm{P}$ and $\mathrm{P}+\mathrm{E}$ after co-ensiling. The results indicated that inoculation of L. plantarum A1 enhanced the fermentation in $\mathrm{PC}$ ratio as lower $\mathrm{pH}$ and higher concentration of lactic acid. The $\mathrm{P}+\mathrm{E}$ additive in $\mathrm{CP}$ ratio had the lowest concentration of acetic acid and there were no differences between others treatments. The DM of the CP ratio before anaerobic digestion was about $450 \mathrm{~g} / \mathrm{kg}$ and the $\mathrm{PC}$ ratio was about $350 \mathrm{~g} / \mathrm{kg}$. After co-ensiling, in $\mathrm{CP}$ ratio, $\mathrm{P}+\mathrm{E}$ had more $\mathrm{DM}$ and $\mathrm{E}$ had lower DM though not significant with $\mathrm{C}$. While, in $\mathrm{PC}$ ratio, $\mathrm{P}+\mathrm{E}$ and $\mathrm{E}$ decreased the $\mathrm{DM}$ than $\mathrm{C}$ and $\mathrm{P}(P<0.001)$. As for the dry matter loss $\left(\mathrm{DM}_{\mathrm{loss}}\right)$, additives increased the $\mathrm{DM}_{\text {loss }}$ than control in the $\mathrm{PC}$ ratio. In the $\mathrm{CP}$ ratio, $\mathrm{P}$ and $\mathrm{E}$ increased and $\mathrm{P}+\mathrm{E}$ decreased the $\mathrm{DM}_{\text {loss }}$ while no significance with control. The more biomass loss during co-ensiling might be due to acetic acid and other volatile producing $[23,24]$ with more ratio of potato pulp. According to report of [22], L. plantarum A1 and combination of $L$. plantarum $\mathrm{A} 1$ and cellulase decreased the $\mathrm{DM}_{\text {loss }}$ of ensiled corn stalk. It might be because 
that the epiphytic microbiota in potato pulp used much of biomass during co-ensiling, especially Citrobacter [25].

\section{Effects of additives, mixture ratios and fermentation time on structural}

\section{carbohydrates compositions and ferulic acid of co-ensiled corn stalk and potato}

\section{pulp}

The potential methane yield of cellulose-rich materials can in most cases only be realized after pre-treatment [26]. Thus, the cellulose and hemicellulose degradation efficiency after co-ensiling of corn stalk and potato pulp with additives were investigated. The effects of mixture ratios, additives on lignocelluloses composition and ferulic acid dynamics after co-ensiling of corn stalk and potato pulp are shown in Table 3. The mixture ratios, additives and fermentation time had appreciable impacts on lignocelluloses compositions after co-ensiling $(P<0.001)$. The content of NDF showed decrease trend with prolonged fermentation time regardless mixture ratios and treatments except for the $\mathrm{PC}$ ratio without additives. The $\mathrm{E}$ and $\mathrm{P}+\mathrm{E}$-treated samples had lower NDF than other treatments in $\mathrm{CP}$ and $\mathrm{PC}$ ratios in all fermentation times except for $\mathrm{P}+\mathrm{E}$-treated samples with $\mathrm{CP}$ ratio at $14 \mathrm{~d}$ of fermentation. Zhang et al., [14] reported that co-ensiling of potato pulp and corn stalk with amounts of $20 \%$ forage reduced about $14 \%$ of NDF content after $50 \mathrm{~d}$ of fermentation. However, the present study showed the co-ensiling of corn stalk and potato pulp in $\mathrm{CP}$ ratio with $\mathrm{P}$ treatment reduced about $3 \%$ of NDF, while the $\mathrm{PC}$ ratio without additives increased $0.37 \%$ of NDF after $90 \mathrm{~d}$ of fermentation. The largest reduction of NDF was about $17 \%$ in $\mathrm{PC}$ ratio with $\mathrm{E}$ treatment, followed by the $\mathrm{CP}$ ratio 
with $\mathrm{E}$ treatment. The differences might be because the differences of mixture ratio of corn stalk and potato pulp resulting in different nutritional ingredient for microbiota fermentation. Furthermore, the cellulase performed well on degradation of lignocelluloses, especially in PC ratio. The effect of co-ensiling time on contents of ADF showed a increased trend from start of fermentation (14 or $30 \mathrm{~d}$ of fermentation) and then decreased in CP ratio of mixtures with additive treatments except for E-treated samples. In addition, the $\mathrm{E}$ and $\mathrm{P}+\mathrm{E}$ treatment reduced more $\mathrm{ADF}$ contents during ensiling in $\mathrm{CP}$ and $\mathrm{PC}$ ratio, respectively. While in the PC ratio, the control group showed increase on ADF contents with prolonged fermentation time, and the fermentation time had no obvious effect on ADF contents in $\mathrm{P}$ and $\mathrm{P}+\mathrm{E}$ treatments. The contents of ADF were higher than that before co-ensiling with $\mathrm{C}$ and $\mathrm{P}$-treated in both $\mathrm{CP}$ and $\mathrm{PC}$ ratios, which might be because that the fermentation consumed more component of DM and less content of lignocelluloses were degraded. The ADL is difficult to degrade, the additives had no obvious effect $(P=0.060)$ on ADL contents after co-ensiling of corn stalk and potato pulp. The $\mathrm{PC}$ ratio had higher ADL contents than $\mathrm{CP}$ ratio, and the highest contents of ADL appeared in all samples after $60 \mathrm{~d}$ of fermentation except for PC ratio without additives.

The PC ratio without additives had higher contents of cellulose than CP ratio without additives during fermentation process, except for 7 and $14 \mathrm{~d}$ of fermentation. The treatment $\mathrm{P}+\mathrm{E}$ decreased much contents of cellulose in $\mathrm{PC}$ ratio than that in $\mathrm{CP}$ ratio during co-ensiling. Cellulose in $\mathrm{CP}$ ratio with $\mathrm{E}$ and $\mathrm{P}+\mathrm{E}$ treatments showed decrease 
trend during co-ensiling but variations in $\mathrm{C}$ and P-treated samples were not obvious. Cellulose in PC ratio treated with E and P indicated increase first and then decrease from day 7 to day 90 of co-ensiling, but $\mathrm{P}+\mathrm{E}$ decreased the contents of cellulose and the opposite result appeared in samples without additives. The hemicelluloses decreased with fermentation process in $\mathrm{CP}$ ratio with $\mathrm{E}$ and $\mathrm{P}+\mathrm{E}$ treatments and in $\mathrm{PC}$ ratio with $\mathrm{P}+\mathrm{E}$ and without additives. Hemicelluloses in $\mathrm{CP}$ ratio without and with $\mathrm{P}$ treatment reduced from 7 to $14 \mathrm{~d}$ of fermentation and after $14 \mathrm{~d}$ the contents were relatively stable.

Lactobacillus plantarum A1 can produce ferulic acid esterase which can break the linkages between lignin and structural polysaccharides of forages. Ferulic acid esterase can release ferulic acid from complex plant cell wall materials [27]. Therefore, FA concentration we detected might be one of the indicators for cell wall degrading efficiency by additives in two ratios of mixture. The results showed that mixture ratios obviously affected the concentration of FA $(P<0.001)$, except for fermentation time of 7 and $90 \mathrm{~d}$. There were no significant differences between treatments and mixture ratios in samples ensiled for 7 and $90 \mathrm{~d}$, P-treated samples showed more concentrations of FA at other fermentation days. That is to say that L. plantarum A1 does produced more ferulic acid esterase and released more ferulic acid. However, combination of other structural carbohydrates, added L. plantarum A1 alone did not displayed advantages on hemicellulose degradation. It might be because the optimize $\mathrm{pH}$ values of ferulic acid esterase produced by L. plantarum A1 is 5.0-7.0, while the $\mathrm{pH}$ were reduced to lower than 4.0 from $7 \mathrm{~d}$ of fermentation (data not shown). Overall, the present study indicated that 
additives $\mathrm{E}$ and $\mathrm{P}+\mathrm{E}$ had better performance on cell wall degradation in $\mathrm{CP}$ and $\mathrm{PC}$ ratios, and the co-ensiling of mixture of corn stalk and potato pulp for 90 days had better performance on lignocelluloses degradation.

\section{Effects of additives, mixture ratios and fermentation times on water soluble carbohydrates of co-ensiled corn stalk and potato pulp}

Carbohydrates especially WSC are as substrates during ensiling. This study determined the influence of additives, mixture ratios and fermentation time and their interactions on the non-structural carbohydrates during co-ensiling of corn stalk and potato pulp (Table 4). In the preset study, the WCS were consumed a lot during the 7-d fermentation (from $42.7 \%$ to $84.1 \%$ ) (Table 1 and 4 ). After 7 -d of fermentation, the WSC concentrations in $\mathrm{C}$ and P-treated samples remained relatively stable until 30 or $60 \mathrm{~d}$ of co-ensiling and then increased. The $\mathrm{E}$ and $\mathrm{P}+\mathrm{E}$ treatments increased the WSC concentrations after $7 \mathrm{~d}$ of co-ensiling and the $\mathrm{PC}$ ratio performed better than $\mathrm{CP}$ ratio. That is to say that the cellulose and hemicellulose degradation approved substances of fermentation and preserved more WSC in samples added with $\mathrm{E}$ and $\mathrm{P}+\mathrm{E}$. In addition, much of available carbohydrates like WSC have been used for producing lactic and acetic acid in samples without additives.

Most forages contain considerable amounts of WSC, made up of mainly glucose, fructose and sucrose [28]. In this study, the three kinds of WSC all reduced a lot during the initial $7 \mathrm{~d}$ of co-ensiling (Table 1 and 4). Fructose and sucrose concentration indicted increase trend in $\mathrm{E}$ and $\mathrm{P}+\mathrm{E}$-treated samples with $\mathrm{CP}$ and $\mathrm{PC}$ ratios after $7 \mathrm{~d}$ of co-ensiling, 
and the concentrations of the two carbohydrates were significantly higher than other treatments during co-ensiling. The changes of fructose were various among different treatments and mixture ratios during co-ensiling. The concentrations of fructose in PC ratio were lower than that in $\mathrm{CP}$ ratio during fermentation, except for $\mathrm{E}$ and $\mathrm{P}+\mathrm{E}$-treated samples with $\mathrm{PC}$ ratio at $90 \mathrm{~d}$ of co-ensiling. Combination with the structural carbohydrates degradation and increase of non-structural carbohydrates during coensiling, we can speculate that the hemicelluloses might be transformed to glucose and sucrose, or transformed other monosaccharides as substances which resulted in more glucose and sucrose preserved. While the reason why much of WSC and fructose in samples with additives especially $\mathrm{P}$ and $\mathrm{P}+\mathrm{E}-$ treated have not been transformed to lactic and acetic acid was unclear. Our previous study indicated that glucose increased in the initial $7 \mathrm{~d}$ of corn stalk silage added with L. plantarum A1 or cellulase, and the fructose and sucrose decreased with start of ensiling [22]. The different trend between the present study and our previous study mainly result from the content of potato pulp, which lead to different microbiota, chemical composition and moisture [29]. These factors approved various conditions of ensiling and combined to influence the fermentation process.

\section{The effects of additives on enzymatic hydrolysis of co-ensiled corn stalk and potato pulp}

The pre-treatment effect of co-ensiling was measured by enzymatic hydrolysis and variables such as GY, CC and relative improvement ratio were compared to that of the additives. Glucose yield representing the amount of glucose released from per DM, the 
CC representing the converted cellulose yield as percentage of the total cellulose [29], relative improvement ratio representing the cellulose convertibility. Interestingly, coensiling of corn stalk and potato pulp without and with L. plantarum A1 improved the GY in the enzymatic hydrolysis than that added with cellulase or their combination, although the $\mathrm{P}+\mathrm{E}$ and $\mathrm{E}$ treatment in $\mathrm{PC}$ ratio had comparable GY at 30 and $60 \mathrm{~d}$ of coensiling, respectively (Fig.1A). These results were in contrast with the results obtained in hemicellulose degradation. Remove the glucose originally contained in the samples after co-ensiling, efficiency of enzymatic hydrolysis did not performed well in samples pretreated with additives. It might be due to the enzymatic hydrolyzed structural carbohydrates to other water soluble carbohydrates like fructose and sucrose in E and $\mathrm{P}+\mathrm{E}$-treated samples (Fig. S1). In addition, it might be because that much hemicellulose had been transformed to available carbohydrates for fermentation in $\mathrm{E}$ and $\mathrm{P}+\mathrm{E}$ treated samples, and the residual fraction of carbohydrates also difficult to be hydrolysis during enzymatic hydrolysis. Furthermore, the degradation of hemicellulose may have led to fibrils losing their supports during co-ensiling, perhaps facilitating a new interaction between cellulose and/or cellulose and lignin, which could have obstructed enzymatic degradation during enzymatic hydrolysis [30].

When translated into $\mathrm{CC}$, the picture changed resulted from the different contents of cellulose in the four treatments among two mixture ratios (Fig. 1B). The highest CC appeared in $\mathrm{PC}$ ratio with $\mathrm{P}+\mathrm{E}$-treated samples and the lowest appeared in E-treated samples at $30 \mathrm{~d}$ of co-ensiling, there were no significant differences in other samples. The 
CCs at $60 \mathrm{~d}$ of co-ensiling were similar with GY. On day of 90, the highest CC was appeared in samples with CP ratio without additives and followed by L. plantarum A1 treatment, no obvious differences in other samples. Additives in $\mathrm{PC}$ ratio preformed better on CC. It might be because that the structure of cellulose from potato pulp is more loosened and porous and lower crystallinity and larger specific surface area than corn stalk, which result in good enzymatic digestibility [31].

The CCs of the co-ensiled samples were compared to the CCs of the mixtures before co-ensiling and a relative improvement ratio was calculated. The relative improvement ratio was similar with CCs on $30 \mathrm{~d}$ of co-ensiling. On d 60, the highest relative improvement ratio was occurred in CP ratio without additives and followed by $\mathrm{P}$ and PC ratio with $\mathrm{E}$ treatment. The relative improvement ratio in $\mathrm{CP}$ ratio without additives on $90 \mathrm{~d}$ of co-ensiling also was the highest, which were followed by $\mathrm{P}$ and $\mathrm{E}$ treatments, respectively, and other samples were no obvious differences. The results of organic acids produced during co-ensiling promoted hydrolysis of lignocellulosic structures, which in turn appear to increase the efficiency of access of the enzymatic hydrolysis to the cellulose [32-34]. Even though, the correlation between organic acids, ferulic acid esterase and cellulase in the lignocellulosic degradation during co-ensiling and enzymatic hydrolysis after co-ensiling is still unclearly.

\section{Theoretical biochemical methane potential of co-ensiled corn stalk and potato pulp}

Theoretical biomethane potential has been used to access methane potential in several studies [35, 36]. Previous studies have focused on hydrolysis of cellulose in 
lignocellulosic materials is reduced by lignin and hemicelluloses, since lignin act as predominant variable to predict methane yield and biodegradability of that substrate. Hence, theoretical methane potential from lignin was also calculated in the present study (Table 5). The two ratios showed very different VS $(P<0.001)$, and the samples of CP ratio with additives had lower VS than control after co-ensiling $(P<0.001)$. The concentrations of TKN were increased by additives, especially $\mathrm{E}$ and $\mathrm{P}+\mathrm{E}$ treatments $(P$ $<0.001)$ after co-ensiling. The $\mathrm{CP}$ ratio had higher TBMP and the $\mathrm{E}$ treatment decreased the TBMP than other groups, while there were no obvious differences of TBMP in PC ratio after co-ensiling. The amounts of lipid and protein were low in corn stalk and potato pulp thus the theoretical methane yield is lower than some other materials [37], and the lower theoretical methane yield in PC ratio mainly due to the lower VS content, as well as in $\mathrm{CP}$ ratio with $\mathrm{E}$ treatment. Thus, the theoretical methane yield calculated with the model we used could not indicate the differences of additives we used, which result from that the model used the average relative molecular weight to each compound (protein, carbohydrate, lipid, lignin, VFA) and did not focus on the potential of pre-treatment of substrates that transformed some compositions into another form that can be easy hydrolysis. Whatever, it needs much of research to standard the equipment, operation conditions, experimental protocols, and calculating methods to obtain a practical and accurate model for pre-treatment of high lignocellulosic materials.

\section{Conclusions}

The additives cellulase alone or in combination with ferulic acid esterase-producing $L$. 
plantarum A1 enhanced the lignocellulosic degradation and preserved more available carbohydrates. The CP ratio exhibited higher theoretical methane yield than PC ratio. Coensiling corn stalk and potato pulp with CP ratio added with cellulase and in combination with L. plantarum A1 for $90 \mathrm{~d}$ could be a better choice for biofuel production. Lactobacillus plantarum A1 did not performed well on lignocellulosic degradation but it in combination with cellulase exhibited better than other treatments. The present study provides a reference for friendly using and pre-treating substances with rich lignocellulose.

\section{Methods}

\section{Feedstock and additives}

Dry corn stalk was collected from Dingxi Minxiang Forage Co., Ltd., Gansu Province, China. The corn stalk had been stored for half a year after naturally drying in the field. After collection, the corn stalk was grinded and sieved through a $6 \mathrm{~mm}$ screen with a fodder grinder. The fresh potato pulp was collected from a potato starch factory, Chankou village, Dingxi city, Gansu province, China. The dry matter (DM) content of potato pulp and corn stalk were approximately 100 and $900 \mathrm{~g} / \mathrm{kg}$ fresh weight (FW), respectively.

Ferulic acid esterase-producing strain Lactobacillus plantarum A1 was previously isolated in Probiotics and Biological Feed Research Center, Lanzhou University. The strain had been confirmed with ability of producing FAE. The optimum temperature and $\mathrm{pH}$ of the FAE produced by L. plantarum A1 was $37^{\circ} \mathrm{C}$ and 6.4 , respectively. The FAE exhibited a good stability in temperature of $25-50^{\circ} \mathrm{C}$ and at $\mathrm{pH}$ of 5.0-7.0 [22]. The other 
additive was a commercial cellulase (Acremonium cellulase, Meiji Seika Pharma Co., Ltd., Tokyo, Japan). The commercial cellulase is a mixture of $\beta$-Glucanase, $\alpha$-Arazyme, $\alpha$ Galactosidase, $\beta$-Galactosidase and $\beta$-Xylanase, which was supplied as freeze-dried powders. According to the manufacturer's descriptions, the cellulase activity is more than $1,000 \mathrm{U} / \mathrm{g}$.

\section{Co-ensiling of corn stalk and potato pulp}

Fraction of the dry corn stalk was rehydrated with distilled water to DM content of approximately $460 \mathrm{~g} / \mathrm{kg} \mathrm{FW}$. The experiment was conducted in a $2 \times 4 \times 5$ factorial design $(2$ mixture ratios $\times 4$ additive treatments $\times 5$ fermentation times). The weight ratio of wet corn stalk and potato pulp was 4:1 (CP), or the weight ratio of dry corn stalk and potato pulp was 1:2 (PC). Four treatments was applied as follows: without additives (C); inoculated FAE-producing L. plantarum A1 with ratio of $5 \times 10^{6} \mathrm{cfu} / \mathrm{g} \mathrm{FW}(\mathrm{P})$; cellulase applied at $0.03 \% \mathrm{FW}(\mathrm{E})$; combination of $L$. plantarum A1 and cellulase (P+E). Each mixture was randomly divided into 60 (3 repetitions $\times 4$ additive treatments $\times$ 5 fermentation times) batches to result in three replicates per additive treatment and time. Each batch was individually treated with the additives. The batches were then ensiled in vacuum-sealed polyethylene plastic bags $(30 \mathrm{~cm} \times 23 \mathrm{~cm})$ with about $300 \mathrm{~g}$ of fresh mixture per bag. The bags were stored at ambient temperature $\left(22-25^{\circ} \mathrm{C}\right)$ and sampled after 7, 14, 30, 60 and $90 \mathrm{~d}$ of fermentation for using. Initial samples were taken before fermentation.

\section{Chemical analysis}

Triplicate mini-silos were opened at each sampling time for chemical analyses. A $20 \mathrm{~g}$ FW samples from each bag was homogenized in $180 \mathrm{ml}$ sterile distilled water with a juice extractor (BA-828, Mannengda Plasthetics Co. Ltd., Guangzhou, China), squeezed for 30 
$\mathrm{s}$ at a high speed, and filtered through four layers of medical gauze. The filtrate $\mathrm{pH}$ was measured with a glass electrode $\mathrm{pH}$ meter immediately. A portion of the filtrate was stored at $-20^{\circ} \mathrm{C}$ for determining water-soluble carbohydrates (WSC) and the rest was acidified with $7.14 \mathrm{~mol} / 1 \mathrm{H}_{2} \mathrm{SO}_{4}$ and filtered with a $0.45-\mu \mathrm{m}$ dialyzer. Lactic acid, acetic acid, propionic acid, and butyric acid were analyzed by High Performance Liquid Chromatography (HPLC, KC-811 column, Shodex; Shimadzu: Japan; oven temperature $50^{\circ} \mathrm{C}$; flow rate $1 \mathrm{ml} \mathrm{min}^{-1}$; SPD $210 \mathrm{~nm}$ ). The content of WSC was estimated using the a methodology described by Thomas [38].

Samples after co-ensiling from each bag were dried by a forced-air oven at $65^{\circ} \mathrm{C}$ for $72 \mathrm{~h}$ and sieved through a mill with $1.0 \mathrm{~mm}$ screen for chemical analyses. Ground samples were analyzed for Kjeldahl N [39]. The content of neutral detergent fiber (NDF), acid detergent fiber (ADF) and acid detergent lignin (ADL) were determined according to the methods of Van Soest et al. [40] using an Ankom 200 fiber analyzer (Ankom Technology, Fairport, NY). During the analysis procedure, heat-stable alpha amylase and sodium sulfite were added. The NDF and ADF were expressed with inclusive of residue ash. The nonstructural carbohydrates concentrations (including glucose, fructose and sucrose) were quantified according to the description of Desta et al. [41]. The ferulic acid (FA) was extracted and determined with HPLC according to the methodology described by Salleh et al. [42]. The content of crude protein, lipid and volatile solids (VS) of samples co-ensiled after $90 \mathrm{~d}$ were determined. Crude protein was calculated as Kjeldahl N (TKN) multiplied by 6.25 . The lipid was extracted with diethyl ether in a soxleth extraction 
instrument. Volatile fatty acids (VFA) were determined according to the methodology described by Lahav et al. [43]. The VS was determined according to standard methods [44].

\section{Enzymatic hydrolysis}

The enzymatic hydrolysis of samples before or after co-ensiling for 30, 60 and $90 \mathrm{~d}$ was conducted according to the description of the National Renewable Energy Laboratory (NREL) [45]. Samples were supplemented with $0.2 \%$ of Acremonium cellulase (Meiji Seika Pharma Co., Ltd., Tokyo, Japan) on the basis of cellulose content. The enzyme blanks were also analyzed. The hydrolysis reaction was performed at $\mathrm{pH} 4.8$ using $0.1 \mathrm{M}$ citrate-phosphate buffer and incubated at $50^{\circ} \mathrm{C}$ and shaken in a shaker at $160 \mathrm{rpm}$ to keep solids in constant suspension for $72 \mathrm{~h}$. The glucose yield (GY) released by enzymatic activities was determined by the HPLC [41] after centrifuged at $10,000 \times \mathrm{g}$ for $10 \mathrm{~min}$ and filtered with $0.22 \mu \mathrm{m}$ membrane. The cellulose convertibility (CC) and relative improvement ratio of the cellulose convertibility were calculated [29].

\section{Theoretical biochemical methane potential (TBMP)}

The theoretical $\mathrm{CH}_{4}$ production was calculated from Bushwell's formula [46]:

$$
\begin{aligned}
& C_{n} H_{a} O_{b}+\left(\mathrm{n}-\frac{a}{4}-\frac{b}{2}\right) H_{2} O \rightarrow\left(\frac{\mathrm{n}}{2}-\frac{a}{8}+\frac{b}{4}\right) \mathrm{CO}_{2}+\left(\frac{\mathrm{n}}{2}+\frac{a}{8}-\frac{b}{4}\right) \mathrm{CH}_{4} \\
& B_{u}=\frac{(n / 2+a / 8-b / 4) 22.4}{12 n+a+16 b}\left(1 \mathrm{CH}_{4} / \mathrm{g} \mathrm{VS}\right)
\end{aligned}
$$

The chemical composition of the VS in the mixtures after $90 \mathrm{~d}$ of co-ensiling was 
calculated with the assumption of an average composition of $\mathrm{VS}_{\text {lipid }}\left(\mathrm{C}_{57} \mathrm{H}_{104} \mathrm{O}_{6}\right), \mathrm{VS}_{\text {protein }}$ $\left(\mathrm{C}_{5} \mathrm{H}_{7} \mathrm{O}_{2} \mathrm{~N}\right)$, VS $\mathrm{S}_{\text {carbohydrate }}\left(\mathrm{C}_{6} \mathrm{H}_{10} \mathrm{O}_{5}\right), \mathrm{VS}_{\text {lignin }}\left(\mathrm{C}_{6} \mathrm{H}_{10} \mathrm{O}_{5}\right)$ and VS VFA $\left(\mathrm{C}_{2} \mathrm{H}_{4} \mathrm{O}_{2}\right)$. The theoretical $\mathrm{CH}_{4}$ production from lipid, protein, carbohydrate, VFA and lignin was calculated as presented by Triolo et al., [33]:

$\mathrm{TBMP}=($ VFA $373+$ Lipid $1014+$ Protein $496+$ Carbohydrate $415+$ Lignin 727 $) 0.001$ With TBMP as $\mathrm{CH}_{4} \mathrm{NL} / \mathrm{kg}$ VS, and VFA, lipid, protein, carbohydrate, and lignin as $\mathrm{g} / \mathrm{kg}$ VS.

\section{Data analysis}

The collected data were analyzed with the GLM procedure of SAS (v 9.4) according to the model for a $2 \times 4 \times 5$ factorial treatment design:

$$
\mathrm{Y}_{\mathrm{ijk}}=\mu+\mathrm{R}_{\mathrm{i}}+\mathrm{D}_{\mathrm{j}}+\mathrm{T}_{\mathrm{k}}+(\mathrm{R} \times \mathrm{D})_{\mathrm{ij}}+(\mathrm{R} \times \mathrm{T})_{\mathrm{ik}}+(\mathrm{D} \times \mathrm{T})_{\mathrm{jk}}+(\mathrm{R} \times \mathrm{D} \times \mathrm{T})_{\mathrm{ijk}}+\mathrm{e}_{\mathrm{ijk}},
$$

where $Y_{i j k}$ is the response variable; $\mu$ is overall mean; $R_{i}$ is effect of mixture ratio $i(I=1$, 2); $D_{j}$ is effect of treatments $j(j=1,2,3,4) ; T_{k}$ is effect of fermentation time $k(k=1,2$, $3,4,5) ;(R \times D)_{i j}$ is effect of interaction between mixture ration $i$ and treatments $j$; $(R \times$ $\mathrm{T})_{\mathrm{ik}}$ is effect of interaction between mixture ratio $\mathrm{i}$ and fermentation time $\mathrm{k} ;(\mathrm{D} \times \mathrm{T})_{\mathrm{jk}}$ is effect of interaction between treatments and fermentation time $\mathrm{j} ;(\mathrm{R} \times \mathrm{D} \times \mathrm{T})_{\mathrm{ijk}}$ is effect of interaction among mixture ratio $\mathrm{i}$, treatments $\mathrm{j}$ and fermentation time $\mathrm{k}$; and $\mathrm{e}_{\mathrm{ijk}}$ is error term. Least squares means were compared using the PDIFF option of SAS. Significance was defined as $P \leq 0.05$. 


\title{
Supplementary information
}

Additional file 1:Fig. S1. Effects of additive and fermentation time on the sucrose yield (SY) and fructose yield (FY) of samples co-ensiled for 30, 60 and $90 \mathrm{~d}$ in the enzymatic hydrolysis.

\begin{abstract}
Abbreviations
C, contral; P, Lactobacillus plantarum A1; E, cellulose; P+E, combination of P and E; CP, weight ratio of wet corn stalk and potato pulp of 4:1; PC, weight ratio of dry corn stalk and potato pulp of 1:2; FAE, ferulic acid esterase; LAB, lactic acid bacteria; DM, dry matter; FW, fresh weight; WSC, water-soluble carbohydrates; NDF; neutral detergent fiber; ADF, acid detergent fiber; ADL, acid detergent lignin; FA, ferulic acid; VS, volatile solids; TKN, Kjeldahl N; VFA; volatile fatty acids; GY, glucose yield; CC, cellulose convertibility; TBMP, Theoretical biochemical methane potential.
\end{abstract}

\section{Acknowledgements}

We thank all the authors contribute to this work and the National Key R\&D Program of China (No. 2017YFE0104300) and National Natural Science Foundation of China (No. 31672487).

\section{Authors' contributions}

DX and XG conceived and designed the study and drafted the manuscript. DX, WK, and JB conducted the experiments. All authors revised and approved the manuscript.

\section{Funding}


This study was financially supported by the National Key R\&D Program of China (No. 2017YFE0104300) and National Natural Science Foundation of China (No. 31672487).

\section{Availability of data and materials}

All data generated or analyzed during this study are included in this published article and its Additional file.

\section{Ethics approval and consent to participate}

Not applicable.

\section{Consent for publication}

Not applicable.

\section{Competing interests}

The authors declare that they have no competing interests.

\section{References}

1. Chynoweth, D.P., Owens, J.M., Legrand, R. Renewable methane from anaerobic digestion of biomass. Renew Energ. 2001; 22, 1-8.

2. Himmel, M.E., Ding, S., Johnson, D.K., Adney, W.S. Biomass

Recalcitrance :Engineering Plants and Enzymes for Biofuels Production. Sci. 2007; $315,804-808$.

3. Kivaisi, A.K., Rubindamayugi, M.S.T. The potential of agro-industrial residues for production of biogas and electricity in Tanzania. Renew Energ. 1996; 9, 917-921. 
4. Zhang, Q., Tang, L., Zhang, J., Mao, Z., Jiang, L. Optimization of thermal-dilute sulfuric acid pretreatment for enhancement of methane production from cassava residues. Bioresource Technol. 2011;102, 3958-3965.

5. Appels, L., Lauwers, J., Degrève, J., Helsen, L., Lievens, B., Willems, K., Impe, J. Van, Dewil, R. Anaerobic digestion in global bio-energy production : Potential and research challenges. Renew Sust Energ Rev. 2011; 15, 4295-4301.

6. Jin, W., Xu, X., Gao, Y., Yang, F., Wang, G. Bioresource Technology Anaerobic fermentation of biogas liquid pretreated maize straw by rumen microorganisms in vitro. Bioresource Technol. 2014; 153, 8-14.

7. Carrillo, F., Colom, X., Su, J.J. Structural FTIR analysis and thermal characterisation of lyocell and viscose-type fibres. Eur Polym J. 2004; 40, 2229-2234.

8. Herrmann, C., Heiermann, M., Idler, C. Effects of ensiling, silage additives and storage period on methane formation of biogas crops. Bioresource Technol. 2011; $102,5153-5161$.

9. Henk, L.L., Linden, J.C. Simultaneous ensiling and enzymatic hydrolysis of structural polysaccharides. Enzyme Microb Technol. 1992;14, 923-930.

10. Nkosi, B.D., Meeske, R. Effects of ensiling totally mixed potato hash ration with or without a heterofermentative bacterial inoculant on silage fermentation, aerobic stability, growth performance and digestibility in lambs. Anim Feed Sci Technol. $2010 ; 161,38-48$

11. Chedly, K., Lee, S. Silage from by-products for smallholders. FAO Plant Prod Prot 
Pap. 2000; 85-96.

12. O'Kiely, P., Moloney, A., O’Roirdan, E.D. Co-ensiling of potatoes with unwilted or wilted grass. Reducing the cost of beef production by increasing silage intake: Beef Production series. 2002; 51, 63-64.

13. Okine, A., Hanada, M., Aibibula, Y., Okamoto, M. Ensiling of potato pulp with or without bacterial inoculants and its effect on fermentation quality, nutrient composition and nutritive value. Anim Feed Sci Technol. 2005; 121, 329-343.

14. Zhang W.W, Zhang Y.G, Liu Z. Effect of different absorbents on fermentation quality of wet potato pulp. J Anim Vet Adv. 2012; 11, 4230-4235.

15. Brezillon, C., Kroon, P.A., Faulds, C.B., Brett, G.M., Williamson, G. Novel ferulic acid esterases are induced by growth of Aspergillus niger on sugar-beet pulp. Appl Microbiol Biot. 1996; 45, 371-376.

16. Micard, V., Thibault, J. Oxidative gelation of sugar-beet pectins : use of laccases and hydration properties of the cross-linked pectins. Carboh Polym. 1999; 39, 265273.

17. Ralet, M.C., Faulds, C.B., Williamson, G., Thibault, J.F. Degradation of feruloylated oligosaccharides from sugar-beet pulp and wheat bran by ferulic acid. Carbohyd Res. 1994; 263, 257-269.

18. Iiyama, K., Lam, T.B.T. Structural characteristics of cell walls of forage grasses their nutritional evaluation for ruminants- review. Asian Austral Journal of Anim Sci. $2001 ; 14,862-879$. 
19. Nsereko, V.L., Smiley, B.K., Rutherford, W.M., Spielbauer, A., Forrester, K.J., Hettinger, G.H., Harman, E.K., Harman, B.R. Influence of inoculating forage with lactic acid bacterial strains that produce ferulate esterase on ensilage and ruminal degradation of fiber. Anim Feed Sci Technol. 2008; 145, 122-135.

20. Lynch, J.P., Jin, L., Lara, E.C., Baah, J., Beauchemin, K.A. The effect of exogenous fibrolytic enzymes and a ferulic acid esterase-producing inoculant on the fibre degradability, chemical composition and conservation characteristics of alfalfa silage. Anim Feed Sci Technol. 2014; 193, 21-31.

21. Jin, L., Duniere, L., Lynch, J.P., Mcallister, T.A., Baah, J., Wang, Y. Impact of ferulic acid esterase producing lactobacilli and fibrolytic enzymes on conservation characteristics, aerobic stability and fiber degradability of barley silage. Anim Feed Sci Technol. 2015; 207, 62-74.

22. Li, F., Ding, Z., Ke, W., Xu, D., Zhang, P., Bai, J. Ferulic acid esterase-producing lactic acid bacteria and cellulase pretreatments of corn stalk silage at two di ff erent temperatures : Ensiling characteristics, carbohydrates composition and enzymatic sacchari fi cation. Bioresource Technol. 2019; 282, 211-221.

23. Hart, E.B., Willaman, J.J. Volatil fatty acids and alcohols in corn silage. J Am Chem Soc. $1912 ; 34,619-1625$.

24. Hafner, S.D., Windle, M., Merrill, C., Smith, M.L., Franco, R.B., Kung, L. Effects of potassium sorbate and Lactobacillus plantarum MTD1 on production of ethanol and other volatile organic compounds in corn silage. Anim Feed Sci Technol. 
$2015 ; 208,79-85$.

25. Kõiv, V., Arbo, K., Maiväli, Ü., Kisand, V., Roosaare, M., Remm, M., Tenson, T. Endophytic bacterial communities in peels and pulp of five root vegetables. Plose One. 2019; 14, e0210542.

26. Petersson, A., Thomsen, M.H., Hauggaard-Nielsen, H., Thomsen, A.B. Potential bioethanol and biogas production using lignocellulosic biomass from winter rye, oilseed rape and faba bean. Biomass Bioenerg. 2007; 31, 812-819.

27. Yu, P., Mckinnon, J.J., Maenz, D.D., Racz, V.J., Christensen, D.A. The interactive effects of enriched sources of Aspergillus ferulic acid esterase and Trichoderma xylanase on the quantitative release of hydroxycinnamic acids from oat hulls. Can J Anim Sci. 2002; 82, 251-257.

28. Pahlow G, Muck R E, Driehuis F, et al. Silage Science and Technology. Agronomy Monograph, no. 42. American Society of Agronomy, Inc. Crop Science Society of America, Inc., Soil Science Society of America, Inc. Madison, WI, USA. 2003.

29. Ambye-Jensen, M., Johansen, K.S., Didion, T., Kádár, Z., Schmidt, J.E., Meyer, A.S. Ensiling as biological pretreatment of grass ( Festulolium Hykor ): The effect of composition, dry matter, and inocula on cellulose convertibility. Biomass Bioenerg. 2013; 58, 303-312.

30. Pihlajaniemi, V., Sipponen, M.H., Liimatainen, H., Sirviö, J.A., Nyyssölä, A., Laakso, S. Weighing the factors behind enzymatic hydrolyzability of pretreated lignocellulose. Green Chem. 2016; 18, 1295-1305.

31. Cheng, L., Hu, X., Gu, Z., Hong, Y., Li, Z., Li, C. Characterization of 
physicochemical properties of cellulose from potato pulp and their effects on enzymatic hydrolysis by cellulase. Int. J. Biol. Macromol. 2019; 131, 564-571.

32. Dewar, W.A., McDonald, P., Whittenbury, R. The hydrolysis of grass hemicelluloses during ensilage. J Sci Food Agr. 1963; 14, 411-417.

33. Chen, Y., Sharma-shivappa, R.R., Chen, C. Ensiling Agricultural Residues for Bioethanol Production. Appl Biochem Biotech. 2007; 143, 80-92.

34. Pakarinen, A., Maijala, P., Jaakkola, S., Stoddard, F.L., Kymäläinen, M., Viikari, L. Evaluation of preservation methods for improving biogas production and enzymatic conversion yields of annual crops. Biotechnol Biofuels. 2011; 4, 20.

35. Triolo, J.M., Sommer, S.G., Møller, H.B., Weisbjerg, M.R., Jiang, X.Y. A new algorithm to characterize biodegradability of biomass during anaerobic digestion : Influence of lignin concentration on methane production potential. Bioresource Technol. 2011; 102, 9395-9402.

36. Li, Y., Zhang, R., Liu, G., Chen, C., He, Y., Liu, X. Comparison of methane production potential, biodegradability, and kinetics of different organic substrates. Bioresource Technol. 2013; 149, 565-569.

37. Møller, H.B., Sommer, S.G., Ahring, B.K. Methane productivity of manure, straw and solid fractions of manure. Biomass Bioenerg. 2004; 26, 485-495.

38. Arthur Thomas, T. An automated procedure for the determination of soluble carbohydrates in herbage. J Sci Food Agr. 1977; 28, 639-642.

39. AOAC, 1990. Official Methods of Analysis Associational of Analytical 
Chemists, 15th edn. Washington, DC.

40. Van Soest, P.J., Robertson, J.B., Lewis, B.A. Methods for Dietary Fiber, Neutral Detergent Fiber, and Nonstarch Polysaccharides in Relation to Animal Nutrition. J Dairy Sci. 1991; 74, 3583-3597.

41. Desta, S.T., Yuan, X., Li, J., Shao, T. Ensiling characteristics, structural and nonstructural carbohydrate composition and enzymatic digestibility of Napier grass ensiled with additives. Bioresource Technol. 2016; 221, 447-454.

42. Salleh, N.H.M., Daud, M.Z.M., Arbain, D., Ahmad, M.S., Ismail, K.S.K. Optimization of alkaline hydrolysis of paddy straw for ferulic acid extraction. Ind Crops Prod. 2011; 34, 1635-1640.

43. Lahav, O., Morgan, B.E., Loewenthal, R.E. Rapid, simple, and accurate method for measurement of VFA and carbonate alkalinity in anaerobic reactors. Environ Sci Technol. 2002; 36, 2736-2741.

44. Clescerl, L.S., Greenberg, A.E. Total, Fixed and Volatile Solids in Solid and Semisolid Samples. Standard Methods for the Examination of Water and Wastewater, LS Clesceri, AE Greenberg, and AD Eaton, Editors. 1998.

45. Selig, M., Weiss, N., Ji, Y. Enzymatic saccharification of lignocellulosic biomass. Laboratory Analytical Procedure (LAP). Golden: National Renewable Energy Laboratory. 2008.

46. Symons, G.E., Buswell, A.M. The methane fermentation of carbohydrates1,2. J Am Chem Soc. 1933; 55, 2028-2036. 
Table 1. Characteristics of mixture of corn stalk and potato pulp before ensiling

\begin{tabular}{lcc}
\hline & \multicolumn{2}{c}{ Mixture ratio $^{1}$} \\
\hline Item $^{2}$ & $6.47 \pm 0.014$ & PC \\
\hline $\mathrm{pH}$ & $448.79 \pm 2.68$ & $354.03 \pm 0.017$ \\
$\mathrm{DM}(\mathrm{g} / \mathrm{kg} \mathrm{FM})$ & $527.26 \pm 2.98$ & $530.70 \pm 2.49$ \\
$\mathrm{DNF}(\mathrm{g} / \mathrm{kg} \mathrm{DM})$ & $270.78 \pm 1.12$ & $278.57 \pm 3.99$ \\
$\mathrm{ADF}(\mathrm{g} / \mathrm{kg} \mathrm{DM})$ & $24.04 \pm 1.62$ & $26.41 \pm 0.11$ \\
$\mathrm{ADL}(\mathrm{g} / \mathrm{kg} \mathrm{DM})$ & $255.73 \pm 0.50$ & $252.15 \pm 1.10$ \\
$\mathrm{CE}(\mathrm{g} / \mathrm{kg} \mathrm{DM})$ & $256.48 \pm 1.86$ & $252.13 \pm 1.50$ \\
$\mathrm{HEM}(\mathrm{g} / \mathrm{kg} \mathrm{DM})$ & $3.68 \pm 0.063$ & $3.36 \pm 0.058$ \\
$\mathrm{FA}(\mathrm{g} / \mathrm{kg} \mathrm{DM})$ & $62.45 \pm 2.46$ & $50.87 \pm 1.74$ \\
$\mathrm{WSC}(\mathrm{g} / \mathrm{kg} \mathrm{DM})$ & $6.41 \pm 0.12$ & $4.37 \pm 0.09$ \\
Sucrose $(\mathrm{g} / \mathrm{kg} \mathrm{DM})$ & $29.26 \pm 0.09$ & $26.20 \pm 0.89$ \\
Glucose $(\mathrm{g} / \mathrm{kg} \mathrm{DM})$ & $39.96 \pm 0.15$ & $37.95 \pm 0.11$ \\
Fructose $(\mathrm{g} / \mathrm{kg} \mathrm{DM})$ & & \\
\hline
\end{tabular}

${ }^{1}$ mean \pm standard error

CP, the weight ratio of wet corn stalk and potato pulp of 4:1; PC, the weight ratio of dry corn stalk and potato pulp of $1: 2$.

${ }^{2} \mathrm{DM}$, dry matter; NDF, neutral detergent fiber (NDF assayed with a heat stable amylase and expressed inclusive of residual ash); ADF, acid detergent fiber; ADL, acid detergent lignin; CE, cellulose; HEM, hemicellulose; FA, ferulic acid; WSC, water soluble carbohydrates. 
Table 2. Characteristics of mixture of potato pulp and dry maize straw after co-ensiling for $90 \mathrm{~d}$.

\begin{tabular}{|c|c|c|c|c|c|c|c|c|c|c|c|c|}
\hline \multirow[t]{2}{*}{ Item $^{1}$} & \multicolumn{4}{|c|}{$\mathrm{CP}^{2}$} & \multicolumn{4}{|c|}{$\mathrm{PC}$} & \multirow[t]{2}{*}{$\mathrm{SEM}^{3}$} & \multicolumn{3}{|c|}{$P$ value $^{4}$} \\
\hline & $\mathrm{C}$ & $\mathrm{P}$ & $\mathrm{E}$ & $\mathrm{P}+\mathrm{E}$ & $\mathrm{C}$ & $\mathrm{P}$ & $\mathrm{E}$ & $\mathrm{P}+\mathrm{E}$ & & $\mathrm{T}$ & $\mathrm{R}$ & $\mathrm{T} \times \mathrm{R}$ \\
\hline $\mathrm{pH}$ & $3.94^{\mathrm{b}}$ & $3.99^{\mathrm{a}}$ & $3.92^{\mathrm{bc}}$ & $3.95^{\mathrm{b}}$ & $3.88^{\mathrm{c}}$ & $3.83^{\mathrm{c}}$ & $3.76^{\mathrm{e}}$ & $3.79^{\mathrm{e}}$ & 0.016 & $<0.001$ & $<0.001$ & 0.001 \\
\hline LA (g/kg DM) & $104.13^{\mathrm{a}}$ & $80.38^{\mathrm{b}}$ & $70.29^{c}$ & $66.24^{\mathrm{d}}$ & $71.29^{c}$ & $79.64^{\mathrm{b}}$ & $72.19^{c}$ & $78.05^{\mathrm{b}}$ & 2.485 & $<0.001$ & 0.046 & $<0.001$ \\
\hline $\mathrm{AA}(\mathrm{g} / \mathrm{kg} \mathrm{DM})$ & $19.32^{\mathrm{a}}$ & $15.13^{\mathrm{ab}}$ & $14.82^{\mathrm{ab}}$ & $13.94^{\mathrm{b}}$ & $15.78^{\mathrm{ab}}$ & $18.32^{\mathrm{ab}}$ & $18.15^{\mathrm{ab}}$ & $18.97^{\mathrm{a}}$ & 0.507 & 0.679 & 0.013 & 0.003 \\
\hline $\mathrm{DM}(\mathrm{g} / \mathrm{kg} \mathrm{FM})$ & $436.48^{\mathrm{ab}}$ & $439.81^{\mathrm{ab}}$ & $433.14^{\mathrm{b}}$ & $441.32^{\mathrm{a}}$ & $336.58^{c}$ & $339.91^{\mathrm{c}}$ & $327.29^{d}$ & $329.98^{d}$ & 10.802 & $<0.001$ & $<0.001$ & 0.007 \\
\hline $\mathrm{DM}_{\text {loss }}(\mathrm{g} / \mathrm{kg} \mathrm{DM})$ & $53.79^{\mathrm{de}}$ & $64.07^{\mathrm{cd}}$ & $65.86^{\mathrm{cd}}$ & $43.02^{\mathrm{e}}$ & $46.18^{\mathrm{e}}$ & $75.98^{c}$ & $99.35^{\mathrm{b}}$ & $118.18^{\mathrm{a}}$ & 0.520 & $<0.001$ & $<0.001$ & $<0.001$ \\
\hline
\end{tabular}

Values with different lowercase letters show significant differences among treatments and two mixture ratios in the same ensiling day $(P<0.05)$. ${ }^{1} \mathrm{DM}$, dry matter; FM, fresh material; LA, lactic acid; AA, acetic acid; $\mathrm{DM}_{\text {loss }}$, dry matter loss.

${ }^{2} \mathrm{CP}$, the weight ratio of wet corn stalk and potato pulp of $4: 1$; PC, the weight ratio of dry corn stalk and potato pulp of $1: 2$.

C, control, no additive; P, Lactobacillus plantarum A1; E, cellulase; P + E, combination of cellulase and Lactobacillus plantarum A1.

${ }^{3} \mathrm{SEM}$, standard error of means.

${ }^{4} \mathrm{~T}$, treatments; $\mathrm{R}$, mixture ratios; $\mathrm{T} \times \mathrm{R}$, the interaction between treatments and mixture ratios. 
Table 3. Effects of mixture ratios, additives on lignocelluloses composition and ferulic acid dynamics after co-ensiling of corn stalk and potato pulp

\begin{tabular}{|c|c|c|c|c|c|c|c|c|c|c|c|c|c|c|c|c|}
\hline \multirow{2}{*}{ Item $^{1}$} & \multirow{2}{*}{$\mathrm{D}^{2}$} & \multicolumn{4}{|c|}{$\mathrm{CP}^{3}$} & \multicolumn{4}{|c|}{$\mathrm{PC}$} & \multirow{2}{*}{$\mathrm{SEM}^{4}$} & \multicolumn{6}{|c|}{$P$ value ${ }^{5}$} \\
\hline & & $\mathrm{C}$ & $\mathrm{P}$ & E & $\mathrm{P}+\mathrm{E}$ & $\mathrm{C}$ & $\mathrm{P}$ & $\mathrm{E}$ & $\mathrm{P}+\mathrm{E}$ & & $\mathrm{T}$ & $\mathrm{R}$ & $\mathrm{D}$ & $\mathrm{T} \times \mathrm{R}$ & $\mathrm{T} \times \mathrm{D}$ & $\mathrm{R} \times \mathrm{D}$ \\
\hline aNDF & 7 & $555.82^{\mathrm{aA}}$ & $564.98^{\mathrm{aA}}$ & $518.03^{\mathrm{cA}}$ & $536.33^{\mathrm{bA}}$ & $519.9^{\mathrm{cB}}$ & $530.99^{\mathrm{bA}}$ & $474.44^{\mathrm{eA}}$ & $496.29^{\mathrm{dA}}$ & 4.150 & $<0.001$ & $<0.001$ & $<0.001$ & $<0.001$ & $<0.001$ & $<0.001$ \\
\hline \multirow[t]{4}{*}{$(\mathrm{g} / \mathrm{kg} \mathrm{DM})$} & 14 & $543.21^{\mathrm{aA}}$ & $531.08^{\mathrm{aC}}$ & $482.07^{\mathrm{bB}}$ & $531.07^{\mathrm{aA}}$ & $520.00^{\mathrm{aB}}$ & $536.43^{\mathrm{aA}}$ & $480.45^{\mathrm{bA}}$ & $481.67^{\mathrm{bB}}$ & 4.129 & & & & & & \\
\hline & 30 & $521.72^{\mathrm{bB}}$ & $549.40^{\mathrm{aB}}$ & $487.03^{\mathrm{cB}}$ & $494.29^{\mathrm{cB}}$ & $518.15^{\mathrm{bB}}$ & $527.24^{\mathrm{bA}}$ & $458.20^{\mathrm{dB}}$ & $462.05^{\mathrm{dC}}$ & 4.620 & & & & & & \\
\hline & 60 & $520.29^{\mathrm{abB}}$ & $531.88^{\mathrm{aC}}$ & $468.27^{\mathrm{dC}}$ & $492.86^{\mathrm{cB}}$ & $524.92^{\mathrm{abAB}}$ & $513.05^{\mathrm{bB}}$ & $453.67^{\mathrm{eB}}$ & $438.33^{\mathrm{fD}}$ & 4.961 & & & & & & \\
\hline & 90 & $511.85^{\mathrm{bB}}$ & $533.72^{\mathrm{aC}}$ & $444.16^{\mathrm{dD}}$ & $463.18^{\mathrm{cC}}$ & $532.49^{\mathrm{aA}}$ & $508.21^{\mathrm{bB}}$ & $446.62^{\mathrm{dB}}$ & $438.94^{\mathrm{dD}}$ & 5.890 & & & & & & \\
\hline $\mathrm{ADF}$ & 7 & $288.63^{\mathrm{cB}}$ & $299.85^{\mathrm{abAB}}$ & $267.49^{\mathrm{eA}}$ & $278.16^{\mathrm{dB}}$ & $291.88^{\mathrm{bcC}}$ & $301.95^{\mathrm{aAB}}$ & $257.63^{\mathrm{fAB}}$ & $272.35^{\mathrm{deA}}$ & 2.289 & $<0.001$ & 0.650 & $<0.001$ & $<0.001$ & $<0.001$ & 0.412 \\
\hline \multirow[t]{4}{*}{$(\mathrm{g} / \mathrm{kg} \mathrm{DM})$} & 14 & $302.74^{\mathrm{abA}}$ & $289.10^{\mathrm{bB}}$ & $263.88^{\mathrm{cAB}}$ & $292.26^{\mathrm{abA}}$ & $302.56^{\mathrm{abB}}$ & $308.26^{\mathrm{aA}}$ & $265.70^{\mathrm{cA}}$ & $267.49^{\mathrm{cA}}$ & 2.879 & & & & & & \\
\hline & 30 & $286.78^{\mathrm{bB}}$ & $307.03^{\mathrm{aA}}$ & $265.05^{\mathrm{cdAB}}$ & $270.97^{\mathrm{cBC}}$ & $300.80^{\mathrm{aB}}$ & $309.71^{\mathrm{aA}}$ & $254.52^{\mathrm{dAB}}$ & $254.42^{\mathrm{dB}}$ & 3.280 & & & & & & \\
\hline & 60 & $286.37^{\mathrm{cB}}$ & $297.91^{\mathrm{bAB}}$ & $256.03^{\mathrm{eB}}$ & $264.89^{\mathrm{dC}}$ & $312.73^{\mathrm{aA}}$ & $297.42^{\mathrm{bAB}}$ & $256.61^{\mathrm{eAB}}$ & $241.14^{\mathrm{fC}}$ & 3.531 & & & & & & \\
\hline & 90 & $284.84^{\mathrm{cB}}$ & $299.30^{\mathrm{bAB}}$ & $237.67^{\mathrm{deC}}$ & $246.38^{\mathrm{dD}}$ & $315.96^{\mathrm{aA}}$ & $294.05^{\mathrm{bB}}$ & $243.51^{\mathrm{deB}}$ & $234.96^{\mathrm{eC}}$ & 4.476 & & & & & & \\
\hline $\mathrm{ADL}$ & 7 & $24.95^{\mathrm{cA}}$ & $24.45^{\mathrm{cB}}$ & $26.19^{\mathrm{cB}}$ & $24.49^{\mathrm{cC}}$ & $30.70^{\mathrm{bB}}$ & $35.61^{\mathrm{aA}}$ & $33.77^{\mathrm{abB}}$ & $31.04^{\mathrm{bB}}$ & 0.698 & 0.060 & $<0.001$ & $<0.001$ & 0.480 & 0.087 & 0.003 \\
\hline \multirow[t]{4}{*}{$(\mathrm{g} / \mathrm{kg} \mathrm{DM})$} & 14 & $26.66^{\mathrm{cdA}}$ & $24.94^{\mathrm{dB}}$ & $29.98^{\mathrm{bcdAB}}$ & $32.18^{\mathrm{bAB}}$ & $30.73^{\mathrm{bcB}}$ & $36.93^{\mathrm{aA}}$ & $30.11^{\mathrm{bcdBC}}$ & $30.19^{\mathrm{bcdB}}$ & 0.635 & & & & & & \\
\hline & 30 & $24.70^{\mathrm{cA}}$ & $25.66^{\mathrm{bcB}}$ & $28.29^{\mathrm{abcB}}$ & $30.38^{\mathrm{abcB}}$ & $29.05^{\mathrm{abcB}}$ & $32.09^{\mathrm{a}}$ & $27.93^{\mathrm{abcC}}$ & $30.89^{\mathrm{abB}}$ & 0.557 & & & & & & \\
\hline & 60 & $31.29^{\mathrm{cA}}$ & $32.20^{\mathrm{cA}}$ & $33.27^{\mathrm{bcA}}$ & $36.50^{\mathrm{abcA}}$ & $33.47^{\mathrm{bcAB}}$ & $40.45^{\mathrm{abA}}$ & $42.82^{\mathrm{aA}}$ & $38.15^{\mathrm{abcA}}$ & 0.803 & & & & & & \\
\hline & 90 & $27.12^{\mathrm{dA}}$ & $28.44^{\mathrm{cdAB}}$ & $27.72^{\mathrm{dB}}$ & $31.86^{\mathrm{bcd} A B}$ & $37.21^{\mathrm{abA}}$ & $34.59^{\mathrm{abcA}}$ & $39.85^{\mathrm{aA}}$ & $34.54^{\mathrm{abcAB}}$ & 0.821 & & & & & & \\
\hline $\mathrm{CE}$ & 7 & $265.19^{\mathrm{bAB}}$ & $273.68^{\mathrm{aA}}$ & $244.91^{\mathrm{dA}}$ & $251.95^{\mathrm{cA}}$ & $261.18^{\mathrm{bB}}$ & $264.14^{\mathrm{bABC}}$ & $221.05^{\mathrm{fBC}}$ & $237.05^{\mathrm{eA}}$ & 2.441 & $<0.001$ & $<0.001$ & $<0.001$ & $<0.001$ & $<0.001$ & $<0.001$ \\
\hline \multirow[t]{4}{*}{$(\mathrm{g} / \mathrm{kg} \mathrm{DM})$} & 14 & $266.36^{\mathrm{aA}}$ & $264.15^{\mathrm{aA}}$ & $233.74^{\mathrm{cAB}}$ & $249.41^{\mathrm{bA}}$ & $277.20^{\mathrm{aA}}$ & $269.84^{\mathrm{aAB}}$ & $235.59^{\mathrm{cA}}$ & $234.55^{\mathrm{cA}}$ & 2.697 & & & & & & \\
\hline & 30 & $264.12^{\mathrm{bAB}}$ & $276.15^{\mathrm{aA}}$ & $235.41^{\mathrm{cAB}}$ & $240.95^{\mathrm{cB}}$ & $271.75^{\mathrm{abA}}$ & $276.09^{\mathrm{aA}}$ & $224.82^{\mathrm{dB}}$ & $221.17^{\mathrm{dB}}$ & 3.282 & & & & & & \\
\hline & 60 & $254.80^{\mathrm{bB}}$ & $268.13^{\mathrm{aA}}$ & $225.92^{\mathrm{cB}}$ & $231.00^{\mathrm{cC}}$ & $277.45^{\mathrm{aA}}$ & $253.69^{\mathrm{bC}}$ & $212.40^{\mathrm{dCD}}$ & $201.00^{\mathrm{eC}}$ & 3.812 & & & & & & \\
\hline & 90 & $257.73^{\mathrm{cAB}}$ & $270.86^{\mathrm{abA}}$ & $209.95^{\mathrm{dC}}$ & $214.53^{\mathrm{dD}}$ & $277.08^{\mathrm{aA}}$ & $261.53^{\mathrm{bcBC}}$ & $206.21^{\mathrm{dD}}$ & $202.84^{\mathrm{dC}}$ & 4.472 & & & & & & \\
\hline HEM & 7 & $264.08^{\mathrm{aA}}$ & $265.14^{\mathrm{aA}}$ & $247.85^{\mathrm{bA}}$ & $261.71^{\mathrm{aA}}$ & $228.29^{\mathrm{cAB}}$ & $230.25^{\mathrm{cA}}$ & $216.81^{\mathrm{dA}}$ & $227.32^{\mathrm{cA}}$ & 2.761 & $<0.001$ & $<0.001$ & $<0.001$ & $<0.001$ & 0.012 & $<0.001$ \\
\hline \multirow[t]{2}{*}{$(\mathrm{g} / \mathrm{kg} \mathrm{DM})$} & 14 & $237.54^{\mathrm{abB}}$ & $242.22^{\mathrm{aB}}$ & $218.19^{\mathrm{dBC}}$ & $238.12^{\mathrm{abB}}$ & $234.25^{\mathrm{bA}}$ & $228.17^{\mathrm{cA}}$ & $214.75^{\mathrm{dA}}$ & $214.18^{\mathrm{dB}}$ & 1.633 & & & & & & \\
\hline & 30 & $229.23^{\mathrm{bB}}$ & $240.42^{\mathrm{aB}}$ & $221.98^{\mathrm{bB}}$ & $222.55^{\mathrm{bCD}}$ & $217.35^{\mathrm{bcCD}}$ & $217.54^{\mathrm{bcB}}$ & $203.68^{\mathrm{dB}}$ & $207.62^{\mathrm{cdB}}$ & 1.846 & & & & & & \\
\hline
\end{tabular}




\begin{tabular}{|c|c|c|c|c|c|c|c|c|c|c|c|c|c|c|c|c|}
\hline \multirow{7}{*}{$\begin{array}{c}\text { FA } \\
(\mathrm{g} / \mathrm{kg} \mathrm{DM})\end{array}$} & 60 & $233.93^{\mathrm{aB}}$ & $233.97^{\mathrm{aB}}$ & $212.23^{\mathrm{bCD}}$ & $229.44^{\mathrm{aBC}}$ & $214.20^{\mathrm{bD}}$ & $213.02^{\mathrm{bB}}$ & $197.07^{\mathrm{CC}}$ & $197.19^{\mathrm{cC}}$ & 2.180 & & & & & & \\
\hline & 90 & $227.01^{\mathrm{abB}}$ & $234.42^{\mathrm{aB}}$ & $206.50^{\mathrm{deD}}$ & $214.27^{\mathrm{dD}}$ & $224.45^{\mathrm{bcBC}}$ & $216.03^{\mathrm{cdB}}$ & $202.89^{\mathrm{eB}}$ & $197.36^{\mathrm{eC}}$ & 1.909 & & & & & & \\
\hline & 7 & $3.09^{\mathrm{aA}}$ & $3.73^{\mathrm{a}} \mathrm{A}$ & $3.25^{\mathrm{abA}}$ & $3.81^{\mathrm{aA}^{\mathrm{A}}}$ & $2.90^{\mathrm{aA}}$ & $3.00^{\mathrm{aA}}$ & $2.95^{\mathrm{aAB}}$ & $2.86^{\mathrm{aAB}}$ & 0.083 & 0.007 & $<0.001$ & 0.012 & $<0.001$ & 0.500 & 0.023 \\
\hline & 14 & $3.21^{\mathrm{abA}}$ & $3.61^{\mathrm{aAB}}$ & $3.15^{\mathrm{bcA}}$ & $3.48^{\mathrm{abA}}$ & $3.25^{\mathrm{abcA}}$ & $3.09^{\mathrm{abcA}}$ & $2.76^{\mathrm{CB}}$ & $2.70^{\mathrm{CB}}$ & 0.076 & & & & & & \\
\hline & 30 & $3.25^{\mathrm{abA}}$ & $3.61^{\mathrm{aAB}}$ & $3.23^{\mathrm{abA}}$ & $3.50^{\mathrm{aA}}$ & $3.21^{\mathrm{abA}}$ & $3.04^{\mathrm{abA}}$ & $2.86^{\mathrm{bAB}}$ & $2.88^{\mathrm{bAB}}$ & 0.064 & & & & & & \\
\hline & 60 & $3.16^{\mathrm{abA}}$ & $3.71^{\mathrm{AA}}$ & $3.26^{\mathrm{abA}}$ & $3.65^{\mathrm{aA}}$ & $3.37^{\mathrm{abA}}$ & $3.00^{\mathrm{abA}}$ & $3.02^{\mathrm{bAB}}$ & $2.87^{\mathrm{bAB}}$ & 0.075 & & & & & & \\
\hline & 90 & $3.34^{\mathrm{aA}}$ & $3.35^{\mathrm{aB}}$ & $3.3 \mathrm{~g}^{\mathrm{aA}}$ & $3.40^{\mathrm{aA}}$ & $3.35^{\mathrm{aA}}$ & $3.42^{\mathrm{aA}}$ & $3.50^{0 \mathrm{AA}}$ & $3.29^{\mathrm{aA}}$ & 0.044 & & & & & & \\
\hline
\end{tabular}

Values with different lowercase letters show significant differences among treatments and two mixture ratios in the same ensiling day, values with different capital letters show significant differences among ensiling days in the same treatment $(P<0.05)$.

${ }^{1}$ aNDF, neutral detergent fiber (NDF assayed with a heat stable amylase and expressed inclusive of residual ash); ADF, acid detergent fiber; ADL, acid detergent lignin; CE, cellulose; HEM, hemicellulos; FA, ferulic acid; DM, dry matter.

${ }^{2} \mathrm{D}$, fermentation time (d).

${ }^{3} \mathrm{CP}$, the weight ratio of wet corn stalk and potato pulp of 4:1; PC, the weight ratio of dry corn stalk and potato pulp of 1:2.

C, control, no additive; P, Lactobacillus plantarum A1; E, cellulase; P + E, combination of cellulase and Lactobacillus plantarum A1.

${ }^{4} \mathrm{SEM}$, standard error of means.

${ }^{5} \mathrm{~T}$, treatments; R, mixture ratios; $\mathrm{D}$, fermentation times $(\mathrm{d})$; $\mathrm{T} \times \mathrm{R}$, the interaction between treatments and mixture ratios; $\mathrm{T} \times \mathrm{D}$, the interaction between treatments and fermentation times; $\mathrm{R} \times \mathrm{D}$, the interaction between mixture ratios and fermentation times; $\mathrm{T} \times \mathrm{R} \times \mathrm{D}$, the interaction between treatments, mixture ratios and fermentation times. 
Table 4. Effects of mixture ratios, additives on water soluble carbohydrates dynamics after co-ensiling of corn stalk and potato pulp

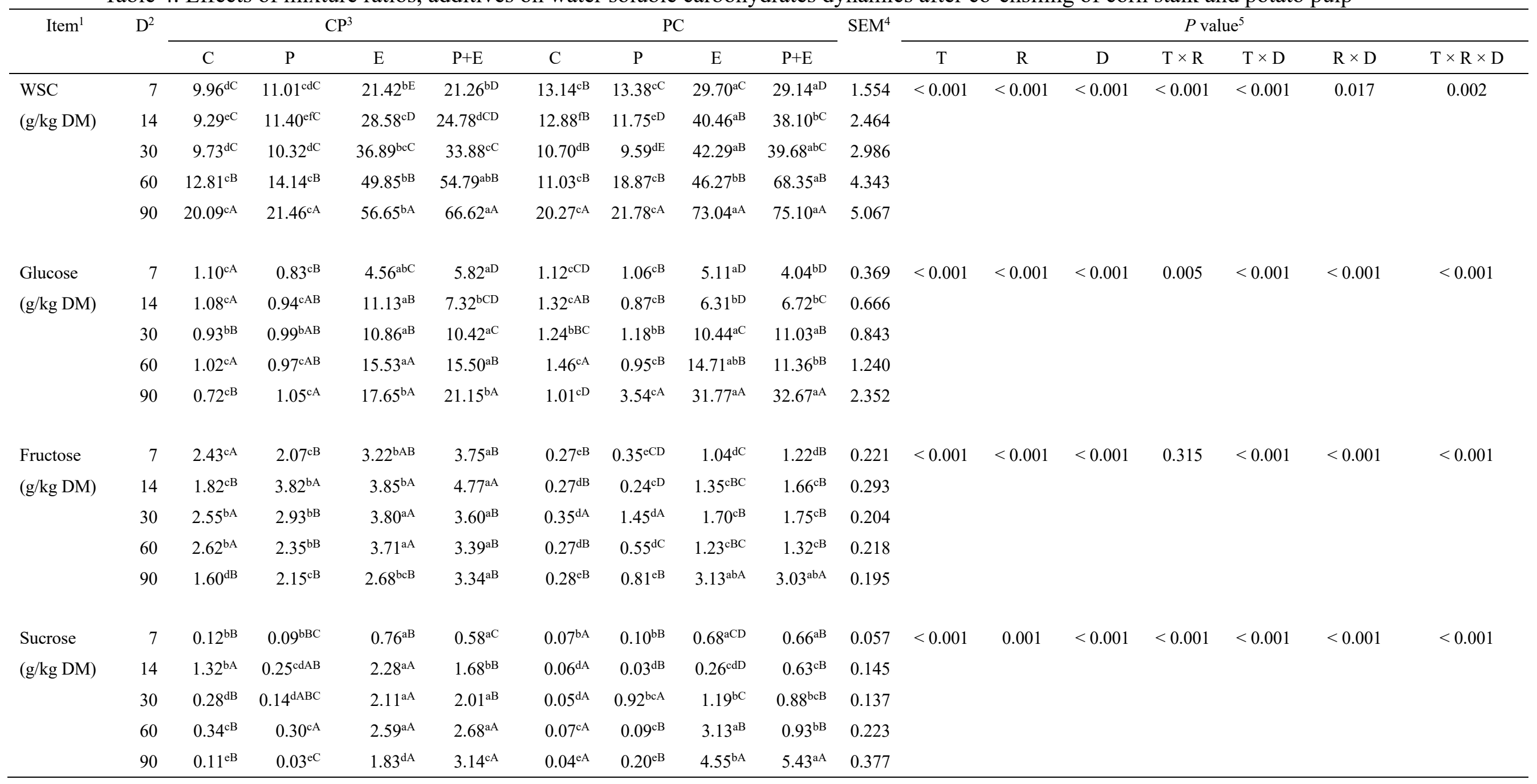

Values with different lowercase letters show significant differences among treatments and two mixture ratios in the same ensiling day, values with different 
capital letters show significant differences among ensiling days in the same treatment $(P<0.05)$.

${ }^{1}$ WSC, water soluble carbohydrates.

${ }^{2} \mathrm{D}$, fermentation time $(\mathrm{d})$

${ }^{3} \mathrm{CP}$, the weight ratio of wet corn stalk and potato pulp of 4:1; PC, the weight ratio of dry corn stalk and potato pulp of $1: 2$.

C, control, no additive; P, Lactobacillus plantarum A1; E, cellulase; P + E, combination of cellulase and Lactobacillus plantarum A1.

${ }^{4} \mathrm{SEM}$, standard error of means.

${ }^{5} \mathrm{~T}$, treatments; R, mixture ratios; $\mathrm{D}$, fermentation times $(\mathrm{d}) ; \mathrm{T} \times \mathrm{R}$, the interaction between treatments and mixture ratios; $\mathrm{T} \times \mathrm{D}$, the interaction between treatments and fermentation times; $\mathrm{R} \times \mathrm{D}$, the interaction between mixture ratios and fermentation times; $\mathrm{T} \times \mathrm{R} \times \mathrm{D}$, the interaction between treatments, mixture ratios and fermentation times. 
Table 5. Composition and theoretical biochemical methane potential of co-ensiled corn stalk and potato pulp

\begin{tabular}{|c|c|c|c|c|c|c|c|c|c|c|c|c|}
\hline \multirow[t]{2}{*}{ Item $^{1}$} & \multicolumn{4}{|c|}{$\mathrm{CP}^{2}$} & \multicolumn{4}{|c|}{$\mathrm{PC}$} & \multirow[t]{2}{*}{$\mathrm{SEM}^{3}$} & \multicolumn{3}{|c|}{$P$ value ${ }^{4}$} \\
\hline & $\mathrm{C}$ & $\mathrm{P}$ & $\mathrm{E}$ & $\mathrm{P}+\mathrm{E}$ & $\mathrm{C}$ & $\mathrm{P}$ & $\mathrm{E}$ & $\mathrm{P}+\mathrm{E}$ & & $\mathrm{T}$ & $\mathrm{R}$ & $\mathrm{T} \times \mathrm{R}$ \\
\hline VS (g/kg DM) & $420.75^{\mathrm{a}}$ & $411.07^{b}$ & $400.87^{c}$ & $409.52^{b}$ & $316.97^{\mathrm{d}}$ & $316.95^{\mathrm{d}}$ & $313.41^{\mathrm{d}}$ & $312.37^{\mathrm{d}}$ & 10.048 & $<0.001$ & $<0.001$ & 0.011 \\
\hline TKN (g/kg DM) & $11.57^{\mathrm{b}}$ & $12.53^{\mathrm{b}}$ & $13.43^{\mathrm{b}}$ & $13.22^{\mathrm{b}}$ & $12.31^{\mathrm{b}}$ & $13.50^{\mathrm{b}}$ & $19.05^{\mathrm{a}}$ & $20.61^{\mathrm{a}}$ & 0.671 & $<0.001$ & $<0.001$ & $<0.001$ \\
\hline TBMP (NL/kg VS) & $189.47^{\mathrm{a}}$ & $186.05^{\mathrm{ab}}$ & $182.33^{b}$ & $186.62^{\mathrm{ab}}$ & $149.18^{\mathrm{c}}$ & $149.61^{\mathrm{c}}$ & $152.12^{\mathrm{c}}$ & $151.15^{\mathrm{c}}$ & 3.748 & 0.213 & $<0.001$ & 0.002 \\
\hline
\end{tabular}

Values with different lowercase letters show significant differences among treatments and two mixture ratios in the same ensiling day $(P<0.05)$.

${ }^{1}$ VS, volatile solids; TKN, total Kjeldahl nitrogen; TBMP, theoretical biochemical methane potential.

${ }^{2} \mathrm{CP}$, the weight ratio of wet corn stalk and potato pulp of 4:1; PC, the weight ratio of dry corn stalk and potato pulp of $1: 2$.

C, control, no additive; P, Lactobacillus plantarum A1; E, cellulase; P + E, combination of cellulase and Lactobacillus plantarum A1.

${ }^{3} \mathrm{SEM}$, standard error of means.

${ }^{4} \mathrm{~T}$, treatments; $\mathrm{R}$, mixture ratios; $\mathrm{T} \times \mathrm{R}$, the interaction between treatments and mixture ratios 


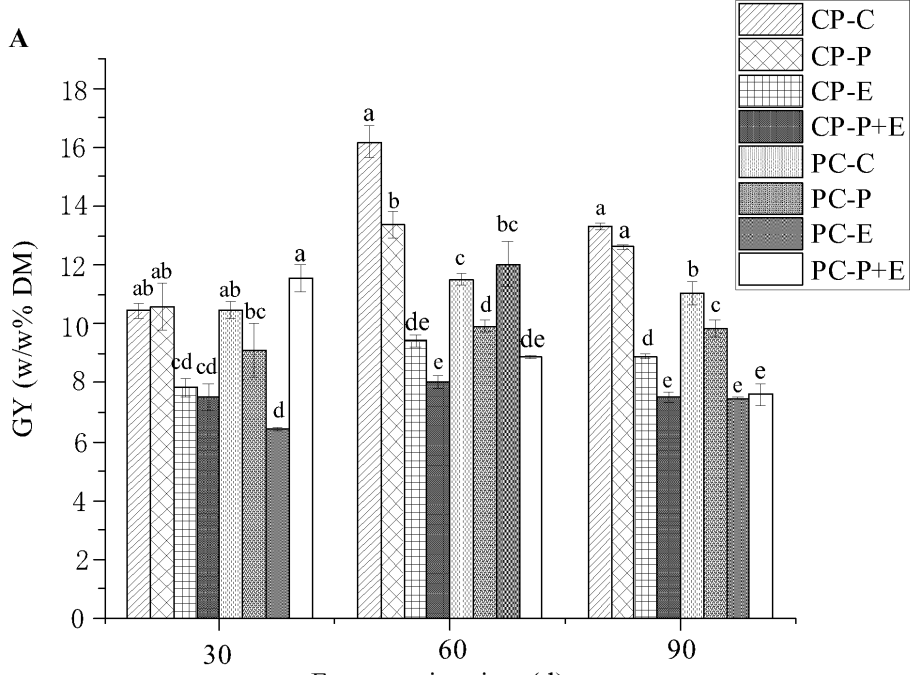

Fermentation time (d)

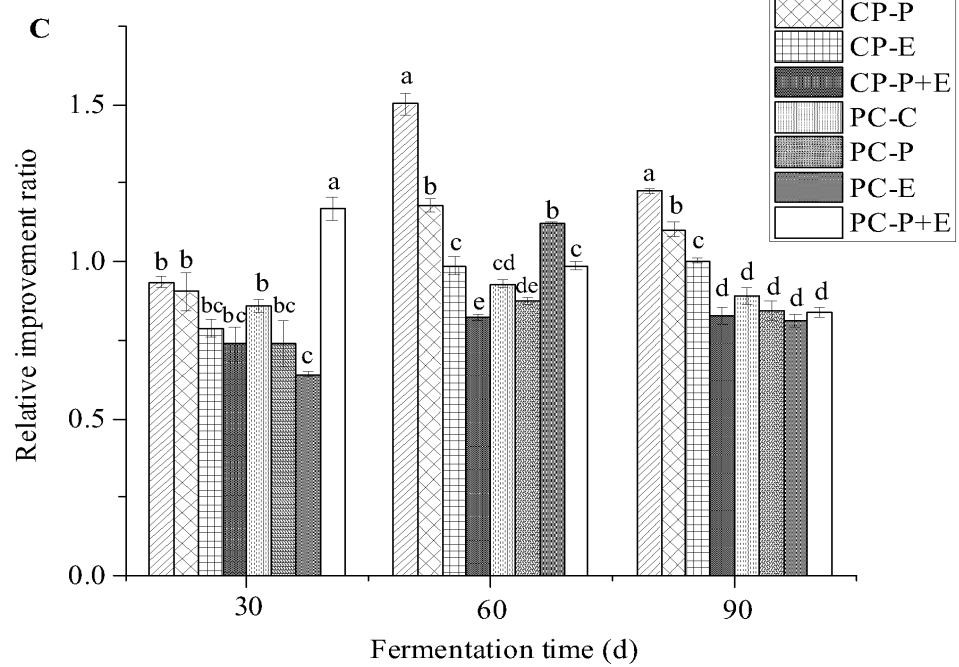

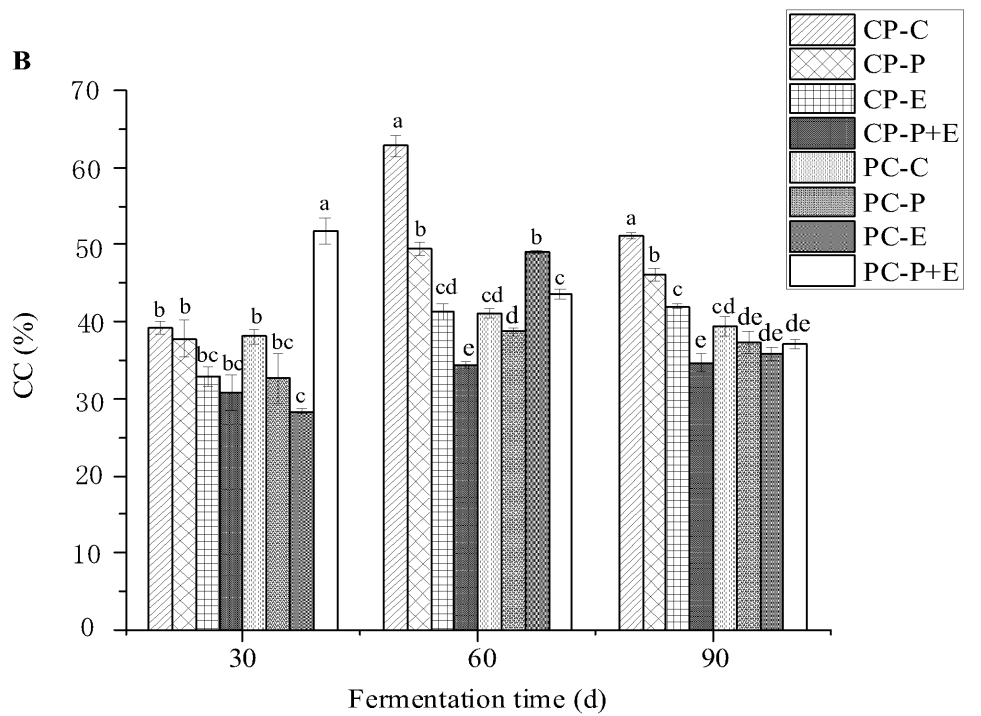

Fig.1 Effects of additive and fermentation time on the glucose yield (GY; A), cellulose convertibility (CC; B) and relative improvement ratio (C) of samples co-ensiled for 30,60 and $90 \mathrm{~d}$ in the enzymatic hydrolysis. $\mathrm{CP}$, the weight ratio of wet corn stalk and potato pulp of $4: 1$; PC, the weight ratio of dry corn stalk and potato pulp of 1:2; C, control, no additive; $\mathrm{P}$, Lactobacillus plantarum $\mathrm{A} 1$; E, cellulase; $\mathrm{P}+\mathrm{E}$, combination of cellulase and Lactobacillus plantarum A1. Means with different letters shows significant difference among treatments and mixture ratios in the same sampling point at $P<0.05(\mathrm{n}=3$, bars indicate standard error of the means). 


\section{Figures}
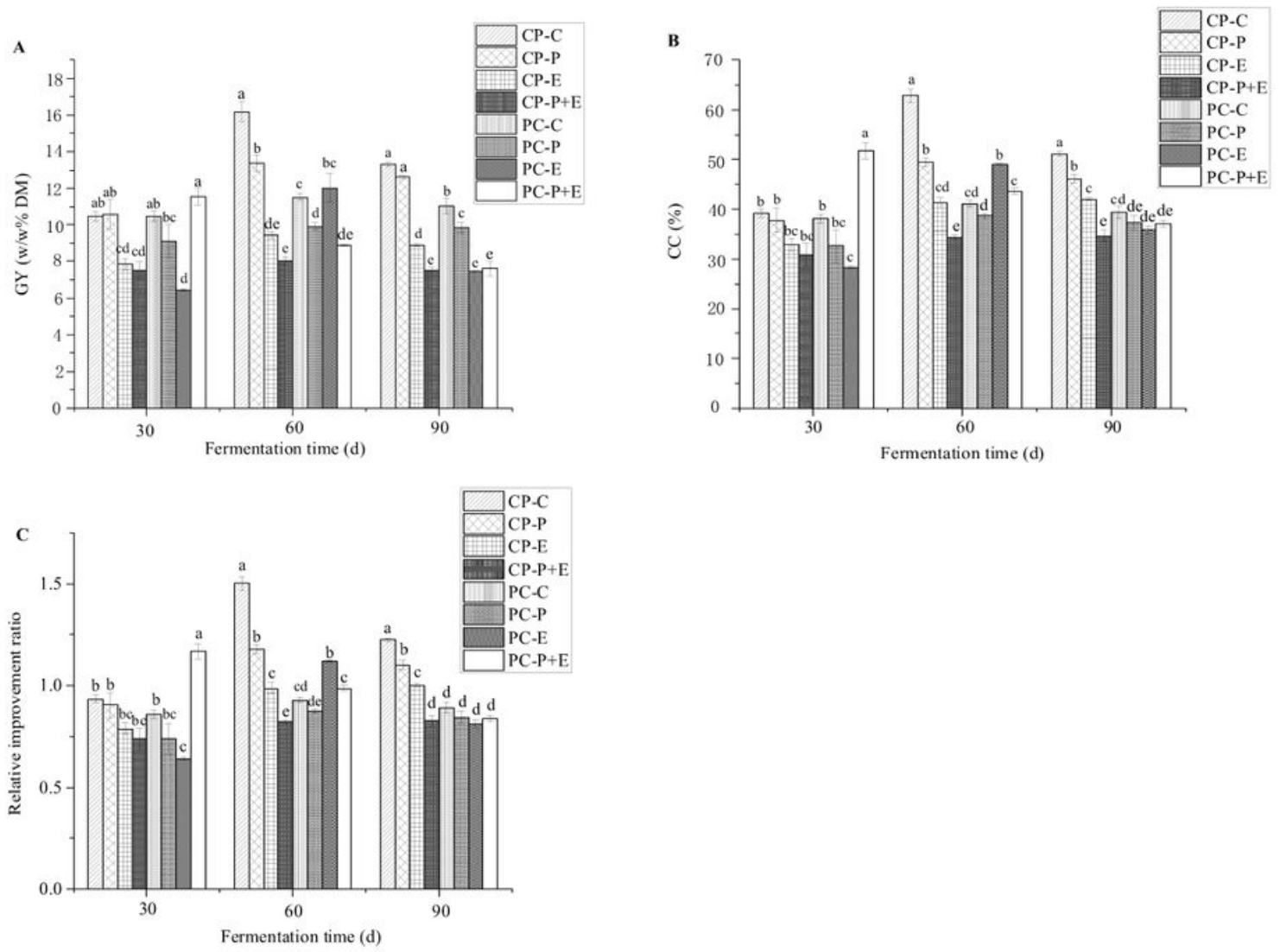

\section{Figure 1}

Effects of additive and fermentation time on the glucose yield (GY;A), cellulose convertibility (CC; B) and relative improvement ratio (C) of samples co-ensiled for 30, 60 and $90 \mathrm{~d}$ in the enzymatic hydrolysis. $\mathrm{CP}$, the weight ratio of wet corn stalk and potato pulp of $4: 1 ; \mathrm{PC}$, the weight ratio of dry corn stalk and potato pulp of 1:2; C, control, no additive; P, Lactobacillus plantarum A1; E, cellulase; $P+E$, combination of cellulase and Lactobacillus plantarum A1. Means with different letters shows significant difference among treatments and mixture ratios in the same sampling point at $P<0.05(n=3$, bars indicate standard error of the means).

\section{Supplementary Files}


This is a list of supplementary files associated with this preprint. Click to download.

- Fig.S1.pdf 